\title{
Endocervical Columnar Cell
}

National Cancer Institute

\section{Source}

National Cancer Institute. Endocervical Columnar Cell. NCI Thesaurus. Code C33914.

A mucus-producing epithelial cell lining the endocervical lumen. 